\title{
ARAHAN REHABILITASI LAHAN PASCA TAMBANG TIMAH UNTUK PENGEMBANGAN WILAYAH DI KABUPATEN BANGKA SELATAN
}

\author{
Direction of Rehabilitation in Post Mine-tin for Regional \\ Development in South Bangka Regency
}

\author{
Fahri Setiawan ${ }^{1}$, Kukuh Murtilaksono$^{2}$, Widiatmaka ${ }^{2}$
}

Diterima: 20 Fenruari 2018 Disetujui: 17 Agustus 2018

\begin{abstract}
Abstrak: Penambangan timah telah meningkatkan perekonomian masyarakat Bangka Selatan, namun meninggalkan lahan-lahan marginal yang harus diperbaiki. Tujuan dari penelitian ini adalah menyusun suatu arahan rehabilitasi lahan pasca tambang timah dari aspek lingkungan, ekonomi dan sosial untuk pengembangan wilayah di Kabupaten Bangka Selatan. Metode yang digunakan adalah digitasi on-screen, Permenhut 60/2009, NPV, BCR, IRR, wawancara, AHP, TOPSIS dan PDRB. Luas lahan pasca tambang timah terbuka di kawasan budidaya adalah 11.224,8 Ha. Berdasarkan Permenhut No. 60/2009 nilai tanaman kelapa sawit 72 dan Karet 71,96. Nilai NPV, BCR dan IRR kelapa sawit Rp 425.629.907,13, 2,83 dan 44\%, sedangkan Karet Rp. 23.440.706,38, 1,19, dan 11\%. Karet dipilih oleh 12 orang stakeholder, sedangkan Kelapa sawit 2 orang. Berdasarkan TOPSIS, tanaman rehabilitasi adalah Kelapa sawit. Kecamatan Tukak Sadai $(0,56)$, Toboali $(0,52)$, dan Air Gegas $(0,51)$ termasuk kategori "Sangat Prioritas", Payung $(0,44)$ dan Simpang Rimba $(0,40)$ "Prioritas", Pulau Besar $(0,32)$ "Cukup Prioritas", Lepar Pongok $(0,13)$ "Kurang Prioritas" dan Kepulauan Pongok $(0,0)$ "Tidak Prioritas" untuk rehabilitasi, dengan memprioritaskan aspek lingkungan. Estimasi sumbangan PDRB pertahun sebesar Rp. 501.824.095.033,34.
\end{abstract}

Kata Kunci: AHP, Kelapa Sawit, PDRB, TOPSIS

\begin{abstract}
Tin Mining rised economic people in South Bangka regency, however mining produced marginal land and was be must fixed. The aim of the research were to arrange a direction of rehabilitation post mine-tin land of enviromental, economy and social aspect for regional development in Bangka Selatan regency. Methodes using were on-screen digitation, forestry ministerial rule 60th year 2009, NPV, BCR, IRR, interview, AHP, TOPSIS and GDP. Post mine-tin land in cultivation area was $11,224.8$ hectare. Based the assesment of forestry ministry rule 60th year 2009 score of oil palm was 72 and rubber was 71.96. NPV, BCR and IRR score of oil palm were Rp. 425,629,907.13, 2.83 and 44\%, while ruber were Rp. 23,440,706.38, 1.19, and $11 \%$. Rubber was selected by 12 stakeholder, while oil palm was 2 stakeholder. Based TOPSIS, rehabilitation plant was oil palm. Distric of Tukak Sadai (0.56), Toboali (0.52), and Air Gegas (0.51) were category "very priority", distric of Payung (0.44) and Simpang Rimba (0.40) were "priority", distric of Pulau Besar (0.32) was "moderate priority", distric of Lepar Pongok (0.13) was "low
\end{abstract}

\footnotetext{
${ }^{1}$ Program Studi Ilmu Perencanaan Wilayah, Sekolah Pascasarjana, Institut Pertanian Bogor

${ }^{2}$ Departemen Ilmu Tanah dan Sumberdaya Lahan, Fakultas Pertanian, Institut Pertanian Bogor
} 
priority", and distric of pongok islands (0.0) was "very low priority" for rehabilitation. Estimated GDP per year of oil palm was Rp. 501,824,095,033.34.

Keywords : AHP, GDP, Oil palm, TOPSIS

\section{PENDAHULUAN}

Penambangan timah telah meningkatkan perekonomian, namun memberikan dampak negatif bagi lingkungan di Kabupaten Bangka Selatan. Rata-rata sumbangan PDRB (Produk Domestik Regional Bruto) pertahun dari sektor pertambangan di tahun 2004-2013 berada di posisi kedua setelah sektor pertanian, yaitu sebesar 328,612 milyar pertahun (BPS Bangka Selatan, 2015). Kabupaten Bangka Selatan memiliki lahan kategori sangat kritis seluas $12.119,0$ ha, kritis $22.375,7$ ha, agak kritis $130.466,0$ ha dan potensial kritis $192.846,2$ ha (DLH BABEL, 2014)

Kegiatan penambangan telah meninggalkan lahan-lahan marginal yang tidak produktif. Tanah lahan pasca tambang (tailing) memiliki sifat fisik, kimia dan biologi tanah yang jelek bila dibandingkan dengan tanah non-tambang. Distribusi ukuran partikel, temperatur, kelembaban, kandungan Nitrogen, Fosfor tersedia, kandungan Kalium, KTK (Kapasitas Tukar Kation) di tanah pasca tambang (tailing) timah sangat buruk (Ang, 1994; Oktavia et al., 2015). Oleh karena itu, perlu diperbaiki dengan penambahan bahan-bahan organik (kotoran ayam), cendawan mikoriza, dan tanah mineral untuk memperbaiki COrganik, basa-basa dapat ditukarkan, N-Total, KTK (Kapasitas Tukar Kation), dan kadar logam berat (Fe, Mn, $\mathrm{Cu}$ dan $\mathrm{Pb}$ ) (Sitorus et al., 2008).

Kegiatan rehabilitasi lahan pasca tambang timah di saat sekarang ini tidak bisa hanya bertujuan untuk memperbaiki lahan-lahan pasca tambang, tetapi juga bisa meningkatkan perekonomian masyarakat di sekitar daerah tambang. Salah satu caranya adalah memanfaatkan lahan tambang untuk perluasan areal pertanian yag produktif (Dariah et al., 2010), dengan menggunakan tanaman perkebunan (karet dan kelapa kelapa sawit), buah (mangga, jeruk dan jambu air), kehutanan (jarak, kayu putih, gaharu, dan sengon) (Gedoan et al., 2013; Inonu, 2008; Inonu, 2011; Sujiman dan Ichwan, 2016; Khodijah, 2008; Lisfiani, 2009; Setiadi dan Adinda, 2013; Tanpibal dan Sahamalu, 1989; Tjahyana dan Ferry, 2011;), dan tanaman-tanaman berpotensi lain dengan tambahan input.

Lahan-lahan pasca tambang timah yang tersebar di Kabupaten Bangka Selatan berpotensi dimanfaatkan untuk kegiatan rehabilitasi sekaligus pertanian dengan menggunakan tanaman perkebunan. Bangka Selatan memiliki 75 Izin Usaha Pertambangan (IUP) operasi produksi, dengan luas 43.350,7 ha di wilayah daratan (Distamben Basel, 2016). Cukup banyaknya IUP ini, berpotensi meninggalkan lahan pasca tambang timah yang perlu direhabilitasi dan berpotensi ditambang kembali oleh penambang ilegal. Hal ini menjadi peluang untuk merehabilitasi lahan-lahan pasca tambang timah dengan menggunakan tanaman perkebunan yang berpotensi meningkatkan perekonomian Kabupaten Bangka Selatan. Berdasarkan latar belakang tersebut, tujuan penelitian ini adalah memberi arahan rehabilitasi lahan pasca tambang timah dari aspek lingkungan, ekonomi dan sosial untuk pengembangan wilayah di Kabupaten Bangka Selatan.

\section{METODE}

\section{Lokasi Penelitian}

Penelitian dilaksanakan di Kabupaten Bangka Selatan, Provinsi Kepulauan Bangka Belitung. Kabupaten Bangka selatan terletak pada $2^{\circ} 26^{\prime} 27^{\prime \prime}$ LS - $3^{\circ} 5^{\prime} 56^{\prime \prime}$ LS dan 107'14'31'" BT - 105 $53^{\prime} 09^{\prime \prime}$ BT. Kabupaten Bangka Selatan memiliki 8 Kecamatan dan 53 Kelurahan/Desa dengan luas keseluruhan 3.607,08 $\mathrm{Km}^{2}$. 


\section{Identifikasi Sebaran Lahan Pasca Tambang Timah Terbuka}

Sebaran lahan pasca tambang timah terbuka diidentifikasi dari citra satelit SPOT 6 tahun 2015 dengan digitasi on-screen. Menurut Ehlers (1991), pengolahan citra satelit multisensor diawali dengan retifikasi (rektifikasi citra berdasarkan referensi, registrasi awal untuk referensi citra, penyempurnaan registrasi, dan pengecekan akurasi), komposit, penajaman citra, dan klasifikasi citra (digitasi). Hasil digitasi dari sebaran lahan pasca tambang timah terbuka ditumpangtindihkan dengan peta pola ruang. Lahan pasca tambang timah terbuka yang bertumpang tindih dengan kawasan budidaya ditetapkan sebagai lahan yang direhabilitasi.

\section{Tanaman yang Sesuai dari Aspek Lingkungan, Ekonomi dan Sosial}

\section{Analisis Indikator Keberhasilan Rehabilitasi}

Indikator keberhasilan rehabilitasi dianalisis berdasarkan Peraturan Menteri (Permen) Kehutanan nomor 60 tahun 2009 tentang Pedoman Penilaian Keberhasilan Reklamasi Hutan. Tingkat keberhasilan rehabilitasi dilakukan perhitungan total nilai evaluasi dengan menggunakan persamaan 1. Penilaian dilakukan kepada perusahaan tambang dan para petani yang telah melakukan rehabilitasi di lahan pasca tambang timah.

$\mathrm{TN}=\sum_{\mathrm{i}=1}^{\mathrm{n}}\left[\frac{\mathrm{TS}_{\mathrm{i}}}{\mathrm{SM}_{\mathrm{i}} \times \mathrm{B}_{\mathrm{i}}}\right]$

$$
\begin{array}{ll}
\mathrm{TN} & =\text { Total Nilai } \\
\mathrm{TS}_{\mathrm{i}} & =\text { Total Skor Penilaian Kriteria i } \\
\mathrm{SM}_{\mathrm{i}} & =\text { Nilai Maksimal Kriteria i } \\
\mathrm{n}=\text { Jumlah Kriteria } & \\
\mathrm{B}_{\mathrm{i}} \quad=\text { Bobot Untuk Kriteria i }
\end{array}
$$

Berdasarkan perhitungan diperoleh kriteria dan kesimpulan sebagai berikut :
1. Nilai $>80$
Baik (diterima).
2. Nilai $60-80$
Sedang (diterima dengan perbaikan mencapai nilai $>80$ ).
3. Nilai $<60$
Jelek (tidak diterima,perlu pemeliharaan intensif).

NPV (Net Present Value), BCR (Benefit Cost Ratio), dan IRR (Internal Rate of Return)

NPV=0 “impas”, NPV $<0$ "tidak layak", dan NPV >0 "layak". BCR $>1$ "layak", BCR $<1$ "tidak layak", dan BCR=1 "impas”. Kegiatan layak apabila IRR lebih tinggi dari suku bunga yang ditentukan.

$$
\begin{aligned}
& \mathrm{NPV}=\sum_{\mathrm{t}=1}^{\mathrm{n}} \frac{\mathrm{Bt}}{(1+\mathrm{i})^{\mathrm{t}}}-\sum_{t=1}^{n} \frac{\mathrm{Ct}}{(1+\mathrm{i})^{\mathrm{t}}} \\
& \mathrm{B} / \mathrm{C}=\frac{\sum_{\mathrm{t}=1}^{\mathrm{n}} \mathrm{B}_{\mathrm{t}} /(1+\mathrm{i})^{\mathrm{t}}}{\sum_{\mathrm{t}=1}^{\mathrm{n}} \mathrm{C}_{\mathrm{t}} /(1+\mathrm{i})^{\mathrm{t}}} \\
& \left.I R R=i^{\prime}+\left(i^{\prime \prime}-i\right)^{\prime}\right) \frac{N P V^{\prime}}{N^{\prime}-N P V}
\end{aligned}
$$

Keterangan :

$\mathrm{B}=$ manfaat $(\mathrm{Rp}) ; \mathrm{C}=$ biaya $(\mathrm{Rp}) ; \mathrm{i}=$ tingkat suku bunga; $\mathrm{t}=$ periode $(1,2,3, \ldots, \mathrm{n})$

$\mathrm{i}^{\prime}=$ discount rate $\mathrm{NPV}(+) ; \mathrm{i}^{\prime \prime}=$ discount rate $\mathrm{NPV}(-) ; \mathrm{NPV}=\mathrm{NPV}(+)$; NPV" $=\mathrm{NPV}(-)$

\section{Tanaman Pilihan Stakeholder}

Survei ke lapangan dilakukan untuk melihat preferensi tanaman yang digunakan masyarakat untuk merehabilitasi lahan pasca tambang. Kemudian tanaman-tanaman tersebut dipilih berdasarkan wawancara kepada para stakeholder. 


\section{Tanaman Rehabilitasi}

Tanaman rehabilitasi ditentukan dengan menggunakan metode TOPSIS ( Technique for Order Performance by Similarity to Ideal Solusition). Analisis TOPSIS dilakukan dua tahap, yaitu pemilihan tanaman berdasarkan aspek ekonomi (NPV, BCR dan IRR) dan pemilihan berdasarkan aspek lingkungan (Permenhut 60/2009), aspek ekonomi (hasil analisis TOPSIS NPV, BCR dan IRR), dan aspek sosial (stakeholder). Analisis TOPSIS dibantu oleh perangkat lunak Sanna 7.

\section{Arahan Wilayah Rehabilitasi Lahan Pasca Tambang Timah}

Arahan rehabilitasi lahan pasca tambang timah dianalisis dengan metode TOPSIS (Technique for Order Performance by Similarity to Ideal Solusition) dan AHP (Analytical Hierarchy Process). Menurut Chen dan Hwang (1992), analisis TOPSIS terdiri dari enam tahap, yaitu :

1. Menghitung matriks keputusan ternormalisasi.

2. Menghitung matriks keputusan ternormalisasi terbobot. Menentukan solusi ideal dan negatif-ideal.

3. Menghitung pemisahan pengukuran. Pemisahan antara setiap alternatif bisa diukur oleh jarak eucladiean $\mathrm{n}$-dimensional.

4. Menghitung kedekatan relatif untuk solusi ideal.

5. Mengurutkan peringkat preferensi.

Analisis AHP digunakan untuk memberikan bobot kepada kriteria. Analisis AHP dibantu dengan perangkat lunak expert choice. Menurut Saaty (2008) prosedur dalam melakukan AHP terdiri dari empat langkah, yaitu :

1. Menentukan masalah dan tujuan dari berbagai jenis informasi yang dicari.

2. Menyusun hierarki keputusan dari atas sebagai tujuan, kemudian objektivitas-objektivitas dari sebuah perspektif luas, melalui tingkatan-tingkatan menengah (kriteria yang mengikuti elemen-elemen terikat) ke tingkatan terendah (yang mana biasanya sebagai sebuah kumpulan alternatif-alternatif)

3. Membangun sebuah kumpulan matriks-matriks perbandingan berpasangan. Setiap elemen di tingkatan di atas digunakan untuk membandingkan elemen-elemen terdekat di tingkatan bawah dengan yang diacu olehnya.

4. Menggunakan perolehan prioritas-prioritas dari perbandingan untuk pembobotan prioritas-prioritas di bawah tingkatan terdekat. Dilakukan untuk setiap elemen. Kemudian setiap elemen di tingkatan bawah ditambah bobot nilai-nilai dan menghasilkan prioritas seluruh atau prioritas global. Dilanjutkan dengan proses pembobotan dan penambahan sampai prioritas-prioritas akhir alternatif-alternatif di tingkatan paling bawah dihasilkan.

Daerah-daerah rehabilitasi di Kabupaten Bangka Selatan dikategorikan berdasarkan nilai $\mathrm{C}_{\mathrm{i}}^{+}$pada analisis TOPSIS dengan menggunakan persamaan 5. Pengkategorian dijabarkan ke rentang skala dengan mempertimbangkan informasi interval.

Interval $=\frac{\text { Nilai Maksimum }- \text { Nilai Minimum }}{\text { Banyak kelas }}$

\section{Dampak Rehabilitasi Lahan Pasca Tambang Timah untuk Ekonomi Wilayah}

Analisis yang digunakan untuk menganalisa dampak rehabilitasi terhadap ekonomi wilayah adalah Kontribusi PDRB (Produk Domestik Regional Bruto). Kontribusi penambahan PDRB dari kegiatan rehabilitasi lahan pasca tambang timah dihitung menggunakan persamaan 6 .

$\mathrm{PDRB}=\sum_{\mathrm{i}=1}^{\mathrm{n}}$ Produksi Barang dan Jasa $\mathrm{i}_{\mathrm{i}}$ Intermediate Cost $\mathrm{i}_{\mathrm{i}}$ 


\section{HASIL DAN PEMBAHASAN}

\section{Sebaran Lahan Pasca Tambang Timah Terbuka}

Lahan pasca tambang timah yang masih terbukan di Kabupaten Bangka Selatan seluas $11.647,8$ ha atau 3,8\% dari luas Kabupaten Bangka Selatan. Lahan pasca tambang timah terbuka paling luas berada di Kecamatan Toboali kemudian diikuti oleh Air Gegas, Payung, Lepar Pongok, Tukak Sadai, Simpang Rimba, dan Pulau Besar. Kepulauan Pongok tidak memiliki lahan pasca tambang timah terbuka.

Lahan pasca tambang timah terbuka di kawasan lindung berada di pola ruang hutan lindung dan kawasan bergambut. Kegiatan penambangan di kawasan lindung harus dikendalikan karena tidak boleh dilaksanakan kegiatan yang mengakibatkan terganggunya fungsi kawasan tersebut. Hutan lindung perlu dibina dan pertahanakan sebagai hutan dengan penutpan vegetasi secara tetap untuk kepentingan hidro-orologi yaitu mengatur tata air, mencegah banjir dan erosi, memelihara keawetan dan kesuburan tanah, baik dalam kawasan hutan yang bersangkutan maupun kawasan sekitarnya yang dipengaruhi (Hardjowigeno dan Widiatmaka, 2007).

Lahan pasca tambang timah terbuka terluas di kawasan budidaya berada pada pola ruang hutan produksi, kemudian perkebunan, hutan rakyat, pertanian tanaman pangan, pertanian holtikultura, kawasan pertambangan, kawasan industri, permukiman perkotaan, wilayah pertambangan rakyat (WPR) dan permukiman perdesaan (Tabel 1). Kegiatan penambangan secara langsung dan cukup signifikan berpengaruh kepada perubahan penggunaan lahan (Yulita, 2011). Lahan pasca tambang timah terluas di kawasan budidaya berada di Kecamatan Toboali sebesar 4.641,4 ha, diikuti Kecamatan Air Gegas 4.454,2 ha, Payung 1.306,3 ha, Lepar Pongok 336,8 ha, Kecamatan Tukak Sadai 311,9 ha, Kecamatan Simpang Rimba 135 ha, dan Pulau Besar 39,2 ha (Tabel 1).

Tabel 1. Sebaran Lahan Pasca Tambang Timah Terbuka berdasarkan Pola Ruang di Kabupaten Bangka

\begin{tabular}{|c|c|c|c|c|c|c|c|c|c|}
\hline Pola Ruang & Toboali & $\begin{array}{l}\text { Air } \\
\text { Gegas }\end{array}$ & Payung & $\begin{array}{l}\text { Lepar } \\
\text { Pongok }\end{array}$ & $\begin{array}{l}\text { Tukak } \\
\text { Sadai }\end{array}$ & $\begin{array}{l}\text { Simpang } \\
\text { Rimba }\end{array}$ & $\begin{array}{l}\text { Pulau } \\
\text { Besar }\end{array}$ & $\begin{array}{l}\text { Kepulaua } \\
\text { n Pongok }\end{array}$ & Jumlah \\
\hline \multicolumn{10}{|l|}{$\begin{array}{l}\text { Kawasan } \\
\text { Lindung }\end{array}$} \\
\hline Hutan Lindung & 411,8 & - & - & - & - & - & - & - & 411,8 \\
\hline $\begin{array}{l}\text { Kawasan } \\
\text { Bergambut }\end{array}$ & - & 0,4 & - & - & - & - & 10,9 & - & 11,3 \\
\hline Jumlah & 411,8 & 0,4 & - & - & - & - & 10,9 & - & 423,1 \\
\hline \multicolumn{10}{|l|}{$\begin{array}{l}\text { Kawasan } \\
\text { Budidaya }\end{array}$} \\
\hline Hutan Produksi & $3.151,5$ & $1.684,9$ & 387,5 & - & 165,9 & 59,8 & 8,3 & - & $5.457,2$ \\
\hline Perkebunan & 442,2 & $1.662,2$ & 550,7 & 48,6 & - & 47,8 & 21,4 & - & $2.772,9$ \\
\hline Hutan Rakyat & 38,5 & 398,5 & 199,0 & 288,2 & - & - & - & - & 924,3 \\
\hline $\begin{array}{l}\text { Pertanian } \\
\text { Tanaman } \\
\text { Pangan }\end{array}$ & 90,6 & 544,7 & - & - & - & - & 1,0 & - & 636,2 \\
\hline $\begin{array}{l}\text { Pertanian } \\
\text { Holtikultura }\end{array}$ & 538,9 & 11,3 & 25,0 & - & - & - & 1,0 & - & 576,2 \\
\hline Pertambangan & 271,2 & 86,0 & 113,3 & - & - & 27,4 & 7,6 & - & 505,4 \\
\hline Industri & - & - & - & - & 146,7 & - & - & - & 146,7 \\
\hline $\begin{array}{l}\text { Permukiman } \\
\text { Perkotaan }\end{array}$ & 96,7 & 29,4 & 19,4 & - & - & - & - & - & 145,5 \\
\hline
\end{tabular}




\begin{tabular}{llllllllll}
\hline Pola Ruang & Toboali & $\begin{array}{l}\text { Air } \\
\text { Gegas }\end{array}$ & Payung & $\begin{array}{l}\text { Lepar } \\
\text { Pongok }\end{array}$ & $\begin{array}{l}\text { Tukak } \\
\text { Sadai }\end{array}$ & $\begin{array}{l}\text { Simpang } \\
\text { Rimba }\end{array}$ & $\begin{array}{l}\text { Pulau } \\
\text { Besar }\end{array}$ & $\begin{array}{l}\text { Kepulaua } \\
\text { n Pongok }\end{array}$ & Jumlah \\
\hline $\begin{array}{l}\text { Wilayah } \\
\begin{array}{l}\text { Pertambangan } \\
\text { Rakyat }\end{array}\end{array}$ & - & 31,0 & - & - & - & - & - & - & 31,0 \\
$\begin{array}{l}\text { Permukiman } \\
\text { Pedesaan }\end{array}$ & 11,7 & 6,2 & 11,4 & - & - & - & - & - & 29,3 \\
Jumlah & $4.641,4$ & $4.454,2$ & $1.306,3$ & 336,8 & 311,9 & 135,0 & 39,2 & - & $11.224,7$ \\
\hline
\end{tabular}

\section{Tanaman yang Sesuai Aspek Lingkungan, Ekonomi dan Sosial}

Berdasar aspek lingkungan (Permenhut 60/2009), tanaman kelapa sawit lebih baik dari pada tanaman karet. Menurut Khodijah (2008), Pertumbuhan tanaman kelapa sawit di lahan pasca tambang timah dengan tambahan input dikategorikan cukup baik (tinggi tanaman, diamater batang, berat basah tajuk, berat kering tajuk, berat kering akar dan nisbah tajuk akar yang berpengaruh nyata). Berdasarkan aspek ekonomi (NPV, BCR dan IRR), tanaman kelapa sawit lebih unggul bila dibandingkan karet (Tabel 2). Menurut penelitian Muchlis (2008) nilai NPV, BCR dan IRR tanaman kelapa sawit dengan sistem agroforestri dan tanaman hortikultura di lahan pasca tambang batu bara yang telah direklamasi lebih baik bila dibandingkan dengan tanaman karet dengan sistem agroforestri dan tanaman horikultura. Tanaman karet lebih banyak dipilih oleh stakeholder dari pada kelapa sawit (aspek sosial) karena kelapa sawit dianggap merusak lingkungan. Berdasarkan penelitian Muhdi et al. (2015) dan Cesylia (2009), potensi sumbangan biomassa kelapa sawit lebih besar dari pada karet. Taufiq et al. (2013) dan Cahyo et al. (2011) menambahkan, konsumsi air tanaman kelapa sawit $(131,67 \mathrm{~mm} / \mathrm{bulan})$ tidak terlalu berbeda jauh dengan karet $(113,37$ $\mathrm{mm} /$ bulan).

Tabel 2. Matriks Penentuan Tanaman Rehabilitasi berdasarkan Aspek Ekonomi (NPV, BCR, dan IRR) di Kabupaten Bangka Selatan

\begin{tabular}{lllll}
\hline \multirow{2}{*}{ Tanaman } & Kriteria & \multicolumn{2}{l}{} \\
& NPV & BCR & IRR & \multirow{2}{*}{ Ci } \\
\cline { 1 - 4 } Bobot & 0,33 & 0,33 & 0,33 & \\
\hline Karet & Rp 23.440.706,38 & 1,19 & $11 \%$ & 0,00 \\
Sawit & Rp 425.629.907,10 & 2,83 & $44 \%$ & 1,00 \\
\hline
\end{tabular}

Berdasarkan kelima kriteria tersebut dengan menggunakan analisis TOPSIS, maka tanaman yang dipilih adalah tanaman kelapa sawit. Pemilihan tanaman kelapa sawit sebagai tanaman rehabilitasi berdasarkan nilai $\mathrm{Ci}$ dari tanaman kelapa sawit yang lebih tinggi dari tanaman karet (Tabel 3).

Tabel 3. Matriks Penentuan Tanaman Rehabilitasi berdasarkan Aspek Lingkungan (Permenhut 60/2009), Ekonomi, dan Sosial (Stakeholder) di Kabupaten Bangka Selatan

\begin{tabular}{lllll}
\hline \multirow{2}{*}{ Tanaman } & Kriteria & & \\
\cline { 2 - 4 } & Permenhut 60/2009 & Ekonomi & Stakeholder & Ci \\
\cline { 1 - 4 } Bobot & 0,33 & 0,33 & 0,33 & \\
\hline Karet & 71,96 & 0,00 & 12 & 0,45 \\
Sawit & 72,00 & 1,00 & 2 & 0,55 \\
\hline
\end{tabular}




\section{Arahan Wilayah Rehabilitasi Lahan Pasca Tambang Timah}

Penentuan daerah prioritas rehabilitasi didasarkan kepada empat kriteria, yaitu jumlah penyuluh, produksi tanaman perkebunan (kelapa sawit), luas lahan pasca tambang timah, dan jarak lahan pasca tambang timah dengan ibukota Kecamatan. Berdasarkan hasil analisis AHP dari 14 responden, kriteria jumlah penyuluh memiliki bobot yang paling tinggi, yaitu 0,298 . Kemudian diikuti kriteria produksi tanaman perkebunan (kelapa sawit) 0,268, luas lahan pasca tambang timah 0,239, dan jarak lahan pasca tambang timah dengan ibukota Kecamatan 0,195. Kecamatan Toboali memiliki nilai luas lahan pasca tambang timah terbuka dan jumlah penyuluh tinggi. Kecamatan Air Gegas memiliki nilai produksi yang paling tinggi, dan Kecamatan Payung memiliki jarak terdekat antara lahan pasca tambang timah terbuka dengan ibukota Kecamatannya. Nilai Ci tertinggi adalah Kecamatan Tukak Sadai, diikuti oleh Kecamatan Toboali, Air Gegas, Payung, Simpang Rimba, Pulau Besar, Lepar Pongok, dan Kepulauan Pongok. Kecamatan Tukak Sadai, Toboali, dan Air Gegas termasuk kategori "Sangat Prioritas" untuk kegiatan rehabilitasi, sedangkan daerah lain menjadi alternatif (Tabel 4). Prioritas pembangunan perlu dilakukan dalam rangka mengatasi keterbatasan anggaran pembangunan, syarat awal dalam penyusunan anggaran (Kurniasih, 2005), dan menghindari silang pendapat dan perdebatan yang berlarut-larut (Suseno dan Sunarto, 2016).

Tabel 4. Matriks Daerah Prioritas Rehabilitasi di Kabupaten Bangka Selatan

\begin{tabular}{|c|c|c|c|c|c|c|}
\hline \multirow[b]{2}{*}{ Kecamatan } & \multicolumn{4}{|l|}{ Kriteria } & \multirow[b]{2}{*}{$\mathrm{Ci}$} & \multirow[b]{2}{*}{ Kategori } \\
\hline & $\begin{array}{l}\text { Penyuluh } \\
\text { (Orang) }\end{array}$ & $\begin{array}{l}\text { Produksi } \\
\text { (Ton) }\end{array}$ & $\begin{array}{l}\text { Luas } \\
\text { Lahan (ha) }\end{array}$ & $\begin{array}{l}\text { Jarak } \\
(\mathrm{km})\end{array}$ & & \\
\hline Bobot & 0,298 & 0,268 & 0,239 & 0,195 & & \\
\hline Tukak Sadai & 5 & $44.741,16$ & 311,9 & 6,56 & 0,56 & $\begin{array}{l}\text { Sangat } \\
\text { Prioritas }\end{array}$ \\
\hline Toboali & 11 & $13.129,68$ & $4.641,4$ & 11,77 & 0,52 & $\begin{array}{l}\text { Sangat } \\
\text { Prioritas }\end{array}$ \\
\hline Air Gegas & 8 & $17.503,60$ & $4.454,2$ & 11,44 & 0,51 & $\begin{array}{l}\text { Sangat } \\
\text { Prioritas }\end{array}$ \\
\hline Payung & 8 & $11.475,16$ & $1.306,3$ & 5,25 & 0,44 & Prioritas \\
\hline $\begin{array}{l}\text { Simpang } \\
\text { Rimba }\end{array}$ & 7 & $21.043,20$ & 135,1 & 7,46 & 0,40 & $\begin{array}{l}\text { Cukup } \\
\text { Prioritas }\end{array}$ \\
\hline Pulau Besar & 9 & $13.017,60$ & 39,4 & 9,47 & 0,32 & $\begin{array}{l}\text { Cukup } \\
\text { Prioritas }\end{array}$ \\
\hline Lepar Pongok & 3 & 700,31 & 336,8 & 9,54 & 0,13 & $\begin{array}{l}\text { Kurang } \\
\text { Prioritas }\end{array}$ \\
\hline $\begin{array}{l}\text { Kepulauan } \\
\text { Pongok }\end{array}$ & 1 & - & - & 0 & 0 & $\begin{array}{l}\text { Tidak } \\
\text { Prioritas }\end{array}$ \\
\hline
\end{tabular}

Keterangan : Ci = Nilai Kedekatan Relatif untuk Solusi Ideal

\section{Dampak Rehabilitasi Lahan Pasca Tambang Timah untuk Ekonomi Wilayah}

Kegiatan rehabilitasi di lahan seluas $11.224,8$ ha diestimasi memberikan sumbangan PDRB bagi Kabupaten Bangka Selatan sebesar Rp. 501.824.095.033,34. Kontribusi ke PDRB daerah Bangka Selatan sebesar 8,19\% dan ke sektor pertanian, Kehutanan dan perikanan sebesar $21,9 \%$. Estimasi pendapatan rata-rata tanaman kelapa sawit pertahun sebesar Rp. 709.577.334.164,85, dan Intermediate Cost rata-rata pertahun dari kegiatan rehabilitasi di lahan pasca tambang timah terbuka adalah Rp. 207.753.239.131,50. Nilai PDRB sebesar Rp. 501.824.095.033,34 menunjukkan kegiatan rehabilitasi dengan tanaman kelapa sawit di 
Kabupaten Bangka Selatan memberikan nilai tambah sebesar Rp. 501.824.095.033,34. Nilai PDRB dengan pendekatan produksi menunjukkan nilai tambah barang dan jasa yang diproduksi oleh suatu kegiatan/sektor ekonomi dengan cara mengurangkan biaya antara (intermediate cost) dari total produksi bruto sektor atau subsektor tersebut. Nilai tambah sama dengan balas jasa atas ikut sertanya berbagai faktor produksi dalam proses produksi (Tarigan, 2012).

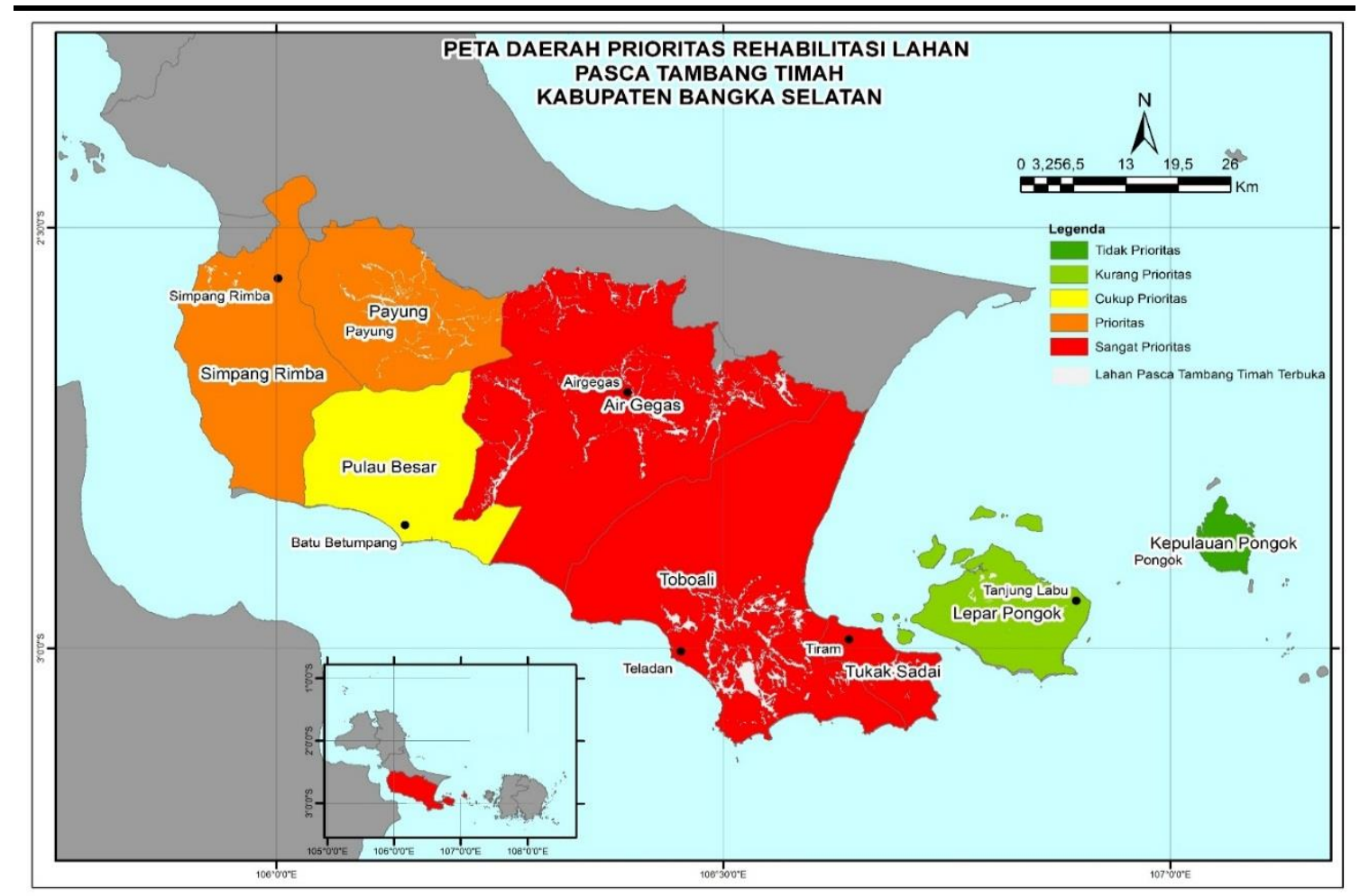

Gambar 1. Daerah Prioritas Rehabilitasi Lahan Pasca Tambang Timah di Kabupaten Bangka Selatan

\section{KESIMPULAN}

Luas lahan pasca tambang timah terbuka di kawasan budidaya sebesar 11.224,7 ha, dengan tanaman kelapa sawit terpilih sebagai tanaman rehabilitasi yang sesuai lingkungan, ekonomi dan sosial untuk merehabilitasi lahan tersebut. Kecamatan Tukak Sadai, Toboali, dan Air Gegas menjadi daerah prioritas dalam kegiatan rehabilitasi (daerah lain sebagai alternatif), dengan estimasi sumbangan PDRB pertahun dari seluruh lahan pasca tambang timah terbuka di kawasan budidaya sebesar Rp. 501.824.095.033,34.

\section{DAFTAR PUSTAKA}

Ang, L.H. (1994). Problems and prospects of afforestation on sandy tin tailings in Peninsular Malaysia. Journal of Tropical Forest Science, 7(1), 87-105.

BPS Bangka Selatan. (2015, Oktober 31). PDRB kabupaten Bangka Selatan menurut lapangan usaha atas dasar harga konstan tahun dasar 2000 (Juta Rupiah). Diambil dari https://bangkaselatankab.bps.go.id.

Cahyo, A.N., Ardika, R., \& Wijaya, T. (2011). Konsumsi air dan produksi karet pada berbagai sistem pengaturan jarak tanam dalam kaitannya dengan kandungan air tanah. J. Penelitian Karet, 29(2), 110-117.

Cesylia, L. (2009). Cadangan karbon pada pertanaman karet di perkebunan karet Bojong Datar PTP Nusantara VIII Kabupaten Pandeglang Banten (Tesis Magister). Diambil dari http://www.repository.ipb.ac.id.

Chen S.J., \& Hwang, C.L. (1992). Fuzzy multiple attribute decision making: methods and apllications. Berlin : Springer-Verlag. 
Dariah, A., Abdurachman, A., \& Subardja, D. (2010). Reklamasi lahan eks-penambangan untuk perluasan areal pertanian. JSL, 4(1), 1-12.

Distamben Basel. (2016). Data IUP Kabupaten Bangka Selatan. Toboali (ID) : Dinas Pertambangan dan Energi Kabupaten Bangka Selatan.

DLH BABEL. (2014). Inventarisasi kerusakan lingkungan (lahan) provinsi kepulauan Bangka Belitung. Pangkal Pinang : DLH BABEL.

Ehlers, M. (1991). Multisensor image fusion techniques in remote sensing. ISPRS, 46, 19-30.

Gedoan, S.P., Hartana, A., Hamim, Widyastuti, U., \& Sukarno, N. (2013). Pertumbuhan tanaman jarak pagar (Jatropha curcas L.) yang ditambahkan cendawan endofit pada lahan pasca tambang timah. JPSL, 3(1), 10-16.

Hardjowigeno, S., \& Widiatmaka. (2007). Evaluasi kesesuaian lahan dan perencanaan tataguna lahan. Yogyakarta : Gadjah Mada University Press.

Inonu, I. (2008). Pengelolaan lahan tailing timah di pulau bangka: penelitian yang telah dilakukan dan prospek ke depan. Enviagro, 2(2),13-22.

Inonu, I. (2011). Toleransi tanaman karet (Hevea brasiliensis Muell. Arg.) di tailing pasir untuk revegetasi lahan pasca tambang timah di pulau Bangka (Disertasi Doktor tidak dipublikasi). Program Pascasarjana Universitas Sriwijaya, Palembang.

Khodijah, N. (2008). Pengujian berbagai jenis amelioran terhadap pertumbuhan bibit kelapa sawit di media bekas tambang timah. Enviagro, 2(1), 1-6.

Kurniasih, D. (2005). Model skala prioritas pembangunan kota Bandung Berbasis good governance. Makara Sosial Humaniora, 9(2), 72-83.

Lisfiani, F. (2009). Kontribusi bahan organik dan anorganik pada pemantapan pertumbuhan jarak pagar (Jatropha curcas) di lahan bekas tambang timah (Tesis Magister). Diambil dari http://www.repository.ipb.ac.id.

Muhdi, Risnasari, I., Bayu, E.S., Hanafiah, D.S., Hutasoit, A., Sitanggang, G.N., \& Silaban, D.S. (2015). Kuantifikasi biomassa perkebunan kelapa sawit di Langkat, Sumatera Utara. J. Pertanian Tropik, 2(1), 17-20.

Muchlis, S. (2008). Model reklamasi lahan pasca tambang batu bara berbasis agroforestri ( studi kasus di kabupaten Kutai Kartanegara dan kabupaten Kutai Timur). (Disertasi Doktor). Diambil dari http://www.repository.ipb.ac.id.

Oktavia, D., Setiadi, Y., \& Hilwan, I. (2015). Comparison of soil properties in heath forest an post-tin mined land: basic for ecosystem restoration. Enviromental Science, 28(1), 124-131.

Saaty, T.L. (2008). Decision making with the analytical hierarchy process. International Journal Services Sciences, 1(1), 83-98.

Setiadi, Y., \& Adinda. (2013). Evaluasi pertumbuhan pohon di lokasi revegetasi lahan pasca tambang PT. Vale Indonesia Tbk. Sorowako, Sulawesi Selatan. J. Silvikultur Tropika, 4(1),19-22.

Sitorus, S.R.P.S., Kusumastuti, E., \& Badri, L.N. (2008). Karakteristik dan teknik rehabilitiasi lahan pasca penambangan timah di pulau Bangka dan Singkep. J. Tanah dan Iklim, 27, 57-74.

Sujiman, \& Ichwan, M. (2016). Kajian teknis upaya keberhasilan revegetasi pada PT. Bara Kumala Sakti kabupaten Kutai Kartanegara provinsi Kalimantan Timur. J. Geologi Pertambangan, 1, 1-11.

Suseno, D.A., \& Sunarto, S.T. (2016). Analisis perencanaan pembangunan desa berbasis undang-undang desa no 6 Tahun 2014 di kecamatan Gunungpati kota Semarang. J. STIE Semarang, 8(2),122-137.

Tanpibal, V., \& Sahumalu, P. (1989). Characteristic and management of tin mine tailings in Thailand. Soil Technology, 2(1), 17-26.

Tarigan, R. (2012). Ekonomi Regional : Teori dan Aplikasi. Jakarta : Bumi Aksara.

Taufiq, M., Siswoyo, H., \& Anggara, W.W.S. (2013). Pengaruh tanaman kelapa sawit terhadap keseimbangan air hutan (studi kasus Sub DAS Landak, DAS Kapuas). J. Teknik Pengairan, 4(1), 47-52.

Tjahyana, B.E., \& Ferry, Y. (2011). Revegetasi lahan bekas tambang timah dengan tanaman karet (Havea brasiliensis). Di dalam Karmawati, E., Prastowo, B., Soetopo, D., \& Hartati, S (eds.),. Prosiding Seminar Nasional Inovasi Perkebunan (pp 117-123). Bogor, Indonesia : Pusat Penelitian dan Pengembangan Perkebunan. 